新潟沿岸における放流サザエの移動と環境特性の関係

\title{
Relationship between environmental characteristics and migration of Japanese turban snail Turbo cornutus on the coast of Niigata, Japan
}

\author{
演岡秀樹 ${ }^{1)}$, * 池田大悟 ${ }^{2)} \cdot$ 石本綾子 $^{2)} \cdot$ 伴田裕之 $^{1)}$ \\ 1) 新潟県水産海洋研究所。 $7950-2171$ 新潟県新潟市西区五十嵐3 の町13098-8 \\ 2) 新潟県水産課. $\bar{T} 950-8570$ 新潟市中央区新光町 4 番地 1
}

\author{
Hideki HAMAOKA $^{1)}$ *, , Daigo IKEDA ${ }^{2)}$, Ryoko ISHIMOTO ${ }^{2)}$ and Hiroyuki HANDA ${ }^{1)}$ \\ 1) Aquaculture Environment Division, Niigata Prefectural Fisheries and Marine Research Institute, 13098-8 Sannomachi, \\ Ikarashi, Niigata 950-2171, Japan \\ 2) Fishery Office, Niigata Prefectural Government, 4-1 Shinko-cho, Chuo-ku, Niigata 950-8570, Japan
}

\begin{abstract}
To understand the relationship between the environmental characteristics and migration habits of the Japanese turban snail Turbo cornutus, we performed tagging and release of turban snails on four fishery-grounds on the coast of Niigata, Japan. We released a total of 4,657 tagged individuals and were able to recapture 168 individuals. The analysis of the recapture data using LASSO-COX proportional hazard model showed that an increase in areas of macroalgal-bed and rocky-bottom suppressed the dispersal of the turban snails from the fishery-grounds. The partial regression coefficient of the area of rocky-bottom was larger than that of the macroalgal-bed, suggesting that an increase in the area of rocky-bottom was more effective in suppressing the dispersal rate of the turban snails from fishery-grounds compared with that of the macroalgalbed. Conversely, an increase in the area of sandy-bottom on the fishery-ground caused an increase in the dispersal rate of the turban snails, even if other environmental characteristics were fixed. The results provide useful information for seed release and habitat construction for the Japanese turban snails.
\end{abstract}

Key Words: habitat characteristics, Japanese turban snail, LASSO-COX proportional hazard model, macroalgal-bed, rockybottom

\section{はじめに}

サザエ Turbo cornutus はアワビ類とともに磯根漁業にお けるもっとも重要な対象種の一つである。日本全国におけ るサザエ漁獲量は 1980 年代に大きく減少したのち安定し ている（早川ら 2007）ものの, 地域的には大きな漁獲変 動が認められることが知られている（臀矢ら 1990）。新潟 県におけるサザエ漁獲量はサザエ刺し網の普及とともに 年々増加し, 1980 年代にピークを迎えたが, その後, 急 激な減少を示したことからサザエ資源の枯渇が懸念されて きた。そのため，1986 年に漁業調整委員会によるサザエ 採捕の殼高制限が指示され, 越後側沿岸では殼高 $60 \mathrm{~mm}$ 未満の個体（小型サザエ）の採捕は禁止となった。この指 示は 2015 年に解除されたが, 資源保護の観点から漁業権 行使規則を定め採捕した小型サザエを自主的に放流してい る。

Received 24 June 2019 Accepted 28 January 2020

* Corresponding author

E-mail: hamaoka.hideki@pref.niigata.lg.jp
サザエ種苗の放流現場において, 海域間で種苗の回収率 に大きな変動が見られることがある（井谷ら 1997）。この 原因の一つとして漁場からの個体の分散が挙げられており （井谷・宗清 1996, 井谷ら 1997）, 飭料環境や住み場所の形 状を含む底質がこの分散に影響を与えていることが指摘さ れている（堀井ら 1997, 井谷・宗清 1999）。しかしながら, これまでの研究では個体の移動に与える要因（植生や底 質）の影響は個別に扱われることが多かった。その理由と しては，植生や底質などの各環境要因間では強い相関関係 が見られることが多く，線形モデルを当てはめる場合には 多重共線性が生じることによって各要因の影響を安定的に 推定することが難しくなるからである（例えば㝨谷 1997)。このような場合, 生物学的・生態学的に説明のつ きにくい係数が推定されることや，解析が不可能になるこ とが起こる。このため, サザエの移動に対する植生や底質 の影響は十分に検討がなされているとは言い難い。近年, このような多重共線性が生じる線形モデルにおいて各要因 の係数の大きさに制約を課すことで安定的に係数を推定で きる手法が開発され，より予測性能の高いモデルを作成す ることが可能になってきた（Hastei et al. 2009）。特に Least absolute shrinkage and selection operator (LASSO) 型正則化 


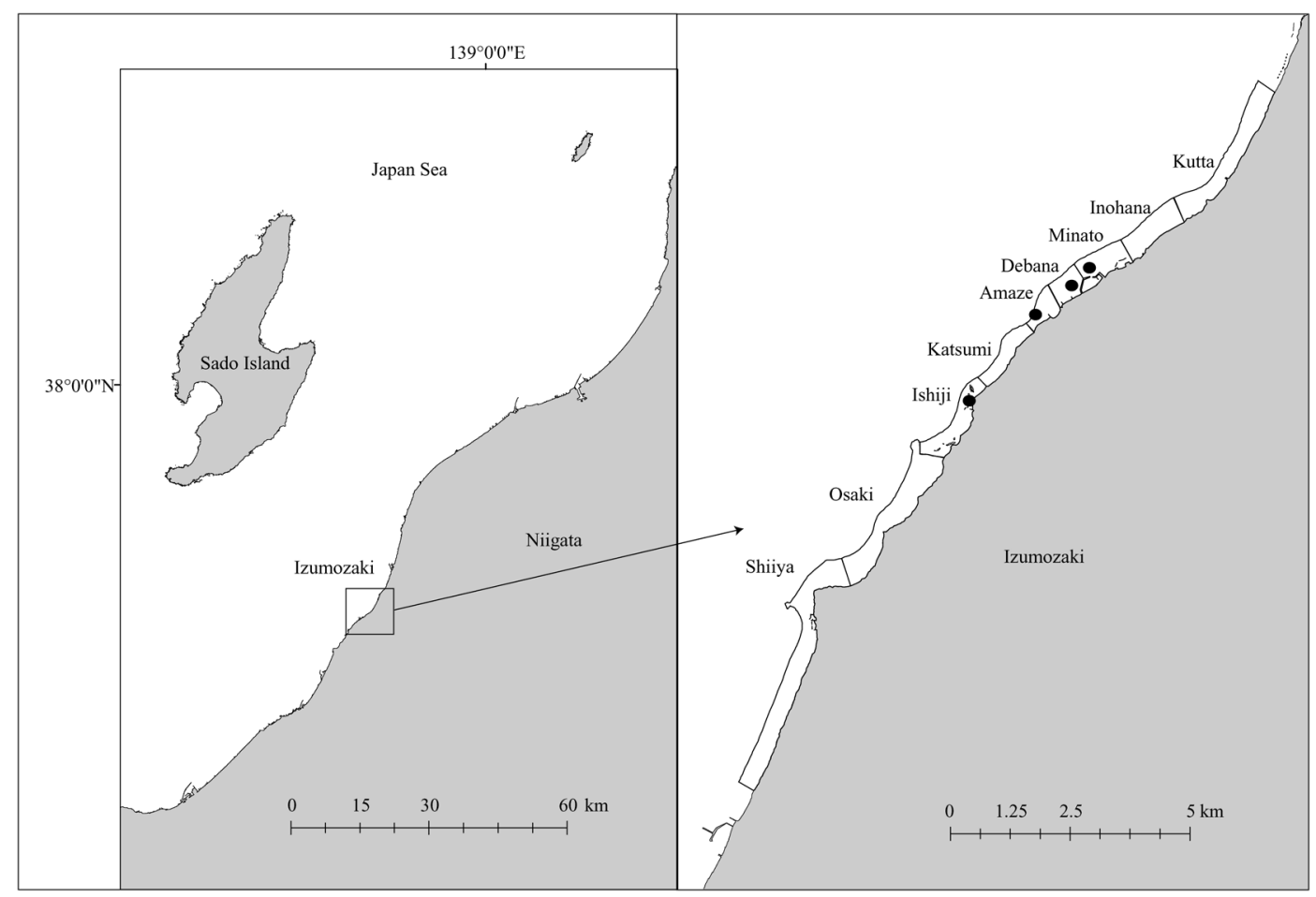

Fig. 1. Map of the study areas. Closed circles indicate the release points.

項の導入は安定的な係数の推定值を得ることができるとと もに説明変数の選択を行うことができる手法として知られ ており（Tibshirani 1996）, 機械学習をはじめ様々な分野で 活用されている。そこで本研究では, サザエの標識放流試 験と LASSO 正則化 COX 比例ハザードモデル（LASSOCOX モデル）を用いて, 放流漁場の植生と底質がサザエ の移動に与える影響を解析した。そして, 植生と底質の相 対的な重要性と放流適地について考察した。

\section{材料と方法}

\section{調査海域}

本研究は新潟漁業協同組合出雲崎支所に所属する漁業者 の操業範囲内で行った。操業範囲は九つの漁場（Fig. 1： 久田, 井の鼻, 港, 出花, 尼瀬, 勝見, 石地, 大崎および 椎谷）に分かれており, 各漁業者はこれら漁場内でサザエ 漁を行っている。多くの場合, 各漁業者は 1 年を通して同 じ漁場でサザエ漁を行い，小型サザエの放流も同じ漁場内 で行っている。

\section{標識放流}

新潟県三島郡出雲崎町地先において，2014～2018 年ま での 5 年間, 毎年 7 8 月にかけて標識放流を実施した。 標識放流には出雲崎地先のサザエ漁場で漁獲された $60 \mathrm{~mm}$ 未満のサザエ（小型サザエ）を用いた。標識放流に先立つ て, 毎年 6 7 月に漁獲された小型サザエに金属製のアバ ロンタグ（株式会社イー・ピー・アイ）を殼口縁辺部に装
着し, 款高を測定した後, 放流漁場ごとに用意した $2 \mathrm{t}$ 水 槽に収容した。その後, 各水槽にろ過海水をかけ流すこと で標識サザエを蓄養した。蓄養中, サザエには2３日に 1 回の頻度で慨料を与えた。蓄養中，標識を施すまでに死 亡した個体がいた（2014 年：10 個体，2015 年：0 個体, 2016 年：0個 体，2017年：14 個 体，2018 年：17 個 体) が，その後の死亡は観察されなかった。各水槽に収容した 標識サザエの殼高中央值を Table 1 に示す。殼高の中央值 は放流群間で最大 $3.4 \mathrm{~mm}$ であった。餌料には配合餌料 （アワビ 4 号, 日本農産工業株式会社）を用い, 体重の約 $1 \%$ にあたる重量を与えた。全ての標識個体は約 3 週間の 蓄養後, 標識が固着したことを確認し, 2014 年は 3 漁場 (港, 出花および尼瀬)，2015 年から 2018 年までは 4 漁場 （港，出花，尼瀬および石地）に放流した（Fig. 1）。

標識放流後, 漁業者によって漁獲された標識サザエを買 取り, 漁獲された漁場と放流から再捕までの日数（経過日 数), 殼高 $(\mathrm{mm})$ を記録した。標識サザエの再捕（買取 り）は最初の標識放流の 2 か月後である 2014 年 11 月 1 日 から 2019 年 2 月 2 日まで行ったが, 放流後 2 か月経過し ていない個体に関しては記録を取らずに再捕された場所に 放流した。放流された漁場と再捕された漁場が一致した場 合を 0 , 両漁場が異なる場合は 1 となるダミーデータを作 成し，移出が起こったかどうか（移出イベント）を示す データとして扱った。そして, ダミーデータを漁場環境が 移出に与える影響の解析に用いた。ただし, 本研究では死 亡個体の記録がないため, 生存しているが再捕できなかっ た個体と死亡したために再捕に至らなかった個体の移出 
Table 1 Median (min-max) values of shell height of released Japanese turban snails in each site from 2014 to 2018.

\begin{tabular}{cccccc}
\hline \multirow{2}{*}{ Release sites } & \multicolumn{5}{c}{ Year } \\
\cline { 2 - 6 } & 2014 & 2015 & 2016 & 2017 & 2018 \\
\hline \multirow{2}{*}{ Amaze } & 57.1 & 58.3 & 57.7 & 57.3 & 60.1 \\
& $(44.2-67.9)$ & $(41.5-65.4)$ & $(43.1-63.4)$ & $(47.3-66.5)$ & $(52.2-68.4)$ \\
\hline \multirow{2}{*}{ Debana } & 56.9 & 58.7 & 57.7 & 57.9 & 59.9 \\
& $(48.9-66.8)$ & $(43.7-64.7)$ & $(39.9-63.2)$ & $(43.0-64.7)$ & $(51.6-67.7)$ \\
\hline \multirow{2}{*}{ Ishiji } & - & 58.4 & 57.7 & 57.6 & 59.9 \\
& & $(51.4-66.9)$ & $(47.3-65.5)$ & $(50.6-67.8)$ & $(45.7-70.0)$ \\
\hline \multirow{2}{*}{ Minato } & 57.3 & 58.8 & 57.7 & 57.9 & 60.3 \\
& $(42.8-64.6)$ & $(47.0-64.5)$ & $(45.7-65.8)$ & $(50.9-66.6)$ & $(47.3-70.0)$ \\
\hline
\end{tabular}

Table 2 Environmental characteristics of the release sites on the coast of Izumozaki.

\begin{tabular}{lcccc}
\hline \multirow{2}{*}{$\begin{array}{c}\text { Release } \\
\text { site }\end{array}$} & \multirow{2}{*}{$\begin{array}{c}\text { Shape of } \\
\text { fishery-ground }\end{array}$} & \multicolumn{3}{c}{ Environmental characteristics } \\
\cline { 3 - 5 } & & Area of macroalgal-bed (ha) & Area of rocky-bottom (ha) & Area of sandy-bottom (ha) \\
\hline Amaze & 15.6 & 2.83 & 27.98 & 1.27 \\
Debana & 18.9 & 7.62 & 21.21 & 6.80 \\
Ishiji & 20.5 & 6.00 & 38.64 & 24.80 \\
Minato & 25.8 & 3.63 & 35.70 & 22.56 \\
\hline
\end{tabular}

ベントについては解析に含めなかった。

\section{漁場環境}

本研究では漁場環境として, 漁場の形状と漁場内の藻 場，砂場及び岩場の面積を用いた。漁場の形状は，各漁場 の面積をその漁場の陸側を除いた周辺長で除した值（漁場 面積 / 周辺長) で表した。この值が小さいほど形状が複雑 であることを示し，ランダムな分散過程による移出しやす さに影響を与えると仮定した。すべての漁場は海岸線から 沖側に向かってなだらかに傾斜しており, サザエ漁は水深 $5 \mathrm{~m}$ 以浅で操業していることから, 平均水深は漁場間で異 ならないと仮定した。各底質の面積の算出には, 平成 29 年度水産基盤整備事業によって行われた音響探査と航空ス ペクトル観測によって得た底質分布図と藻場分布図を用い た。音響探査データと航空スペクトルを用いた底質の判別 手法は海洋調査技術マニュアルに従った（海洋調査協会 2015)。観測で得られた底質と藻場の分布を重稀わせ, 各底質の分布から藻場が分布している部分を削除した。そ の後, 残った底質部分の細砂に分類される部分を砂場, 荒 砂や碟, 巨碟, 岩盤に分類される部分を岩場として各漁場 内での面積を求めた。藻場面積は, 藻場分布図と操業範囲 を重㸚合わせ, 各漁場内の藻場面積を求めた。各面積と漁 場の周辺長の算出には ArcGIS 10.5.1（ESRI 社）を用いた。

\section{統計解析}

解析に先立って漁場環境要因間の関係を見るために, 各 要因間のピアソンの相関係数を算出した。放流後に漁場間
で移動しなかった個体と移動した個体の殸高および再捕ま での日数の比較には Brunner-Munzel test を用いた。漁場環 境が放流サザエの移動に与える影響を調べるため, LASSO-COX モデルを用いた。移出イベントを示すダミー データと経過日数から得られた移出が起こるまでの日数を 目的変数, 漁場の形状と各底質の面積を説明変数とした。 すべての説明変数は平均 0 , 分散 1 になるよう標準化し, 解析に用いた。LASSO-COX モデルにおける正則化パラ メーターである入の值は, 推定值と観測值の平均二乗誤差 が最小となるようにクロスバリデーション法によって決定 した。統計解析にはR 3.4.2 (R Development Core Team 2017), Brunner-Munzel testには lawstat package $の$ brunner. munzel.test 関数, LASSO-COX モデルの構築には glmnet package の glmnet 関数を用いた。

\section{結果}

標識放流が行われた漁場の底質環境を Table 2 に示した。 岩場面積は漁場間で大きな違いは見られなかったが, 藻場 面積や砂場面積は漁場間で異なっていた。藻場面積が比較 的大きな漁場は出花と石地, 砂場面積が比較的大きな漁場 は石地と港であった。各環境要因間における相関係数は一 0.35 から 0.85 の範囲を示し (Table 3), 砂場面積と岩場面 積, また漁場の形状との間で強い相関が見られた（砂場面 積 vs 岩場面積 : 0.85 , 砂場面積 vs 漁場の形状：0.80)。

調査期間中，再捕された標識サザエは 168 個体であり (Table 4), そのうち漁場間で移動しなかった個体と移動し 
Table 3 Correlation matrix between the environmental factors.

\begin{tabular}{lccc}
\hline & Shape of fishery-ground & Area of macroalgal-bed & Area of rocky-bottom \\
\hline Area of macroalgal-bed & -0.03 & & \\
Area of rocky-bottom & 0.55 & -0.35 & 0.85 \\
Area of sandy-bottom & 0.80 & 0.10 & 0.85 \\
\hline
\end{tabular}

Table 4 Total number of Japanese turban snails that were released and recaptured in each fishery-ground.

\begin{tabular}{lccccccc}
\hline \multirow{2}{*}{ Release site } & \multirow{2}{*}{$\begin{array}{c}\text { Total } \\
\text { release number }\end{array}$} & \multirow{2}{*}{$\begin{array}{c}\text { Total } \\
\text { recapture number }\end{array}$} & Amaze & Debana & Ishiji & Minato & Others* \\
\cline { 4 - 7 } & & 10 & 6 & 3 & 1 & 0 & 0 \\
Amaze & 1247 & 31 & 11 & 15 & 0 & 5 & 0 \\
Debana & 1215 & 109 & 0 & 0 & 105 & 3 & 1 \\
Ishiji & 1005 & 18 & 0 & 5 & 0 & 12 & 1 \\
Minato & 1190 & & & & & & \\
\hline
\end{tabular}

*Others indicate Kutta, Inohana, Katsumi, Osaki or Shiiya (also see Fig. 1).
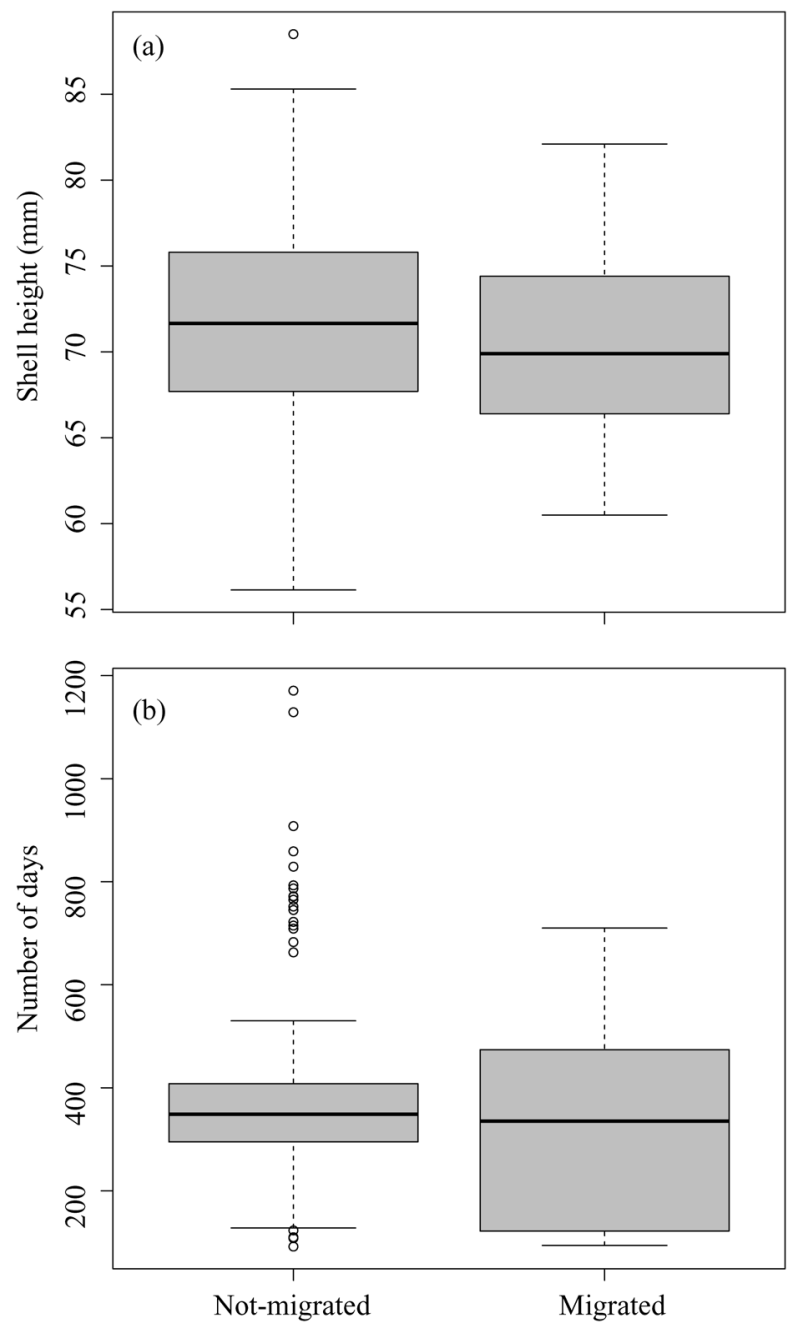

Fig. 2. Boxplots comparing the shell height when the Japanese turban snails were recaptured (a) and the number of days until recaptured (b) between individuals that did not migrate and migrated individuals. Top ends, lower ends, and solid lines indicate 75 percentile, 25 percentile, and median. Error bars indicate maximum and minimum values within 1.5 times of the box height, with outliers as blank circles.
Table 5 Estimated partial regression coefficient of each explanatory variable in the LASSO-COX proportional hazard model.

\begin{tabular}{lc}
\hline Explanatory variable & Estimated partial regression coefficient \\
\hline Shape of fishery-ground & 0.000 \\
Area of macroalgal-bed & -0.918 \\
Area of rocky-bottom & -3.174 \\
Area of sandy-bottom & 1.809 \\
\hline
\end{tabular}

た個体はそれぞれ 138 と 30 個体であった。漁場間で移動 しなかった個体と移動した個体の殼高の中央值はそれぞれ $71.7 \mathrm{~mm}$ と $69.9 \mathrm{~mm}$ であり（Fig. 2a），これらの間に有意 な差は見られなかった (Brunner-Munzel test statistic= $1.1447, \mathrm{df}=43.965, \mathrm{p}=0.2585)$ 。再捕までの日数は最も長 い個体は 1344 日，最も短い個体は 92 日で，その中央值は 346 日であった。再捕までの期間の中央值は, 漁場間で移 動しなかった個体で 348.5 日，移動した個体で 335.5 日で あった（Fig. 2b）。これらの間にも有意な差は見られな かった（Brunner-Munzel test statistic $=0.98937, \mathrm{df}=34.791$, $\mathrm{p}=0.3293)$ 。

モデル解析に先立って算出した入の值は 0.00321724 で あった。この值を基にモデル解析を行った結果, 漁場の形 状のみ偏回帰係数が 0 と推定された（Table 5)。そして, 岩場面積と藻場面積の偏回帰係数は負の值, 砂場面積の偏 回帰係数は正の值であった。偏回帰係数は藻場面積よりも 岩場面積の方が大きかった。

\section{考察}

これまでの野外観察では, サザエは成長に伴い生息場所 を変化させることが知られている（例えば藤井 1998, Hayakawa et al. 2018)。そのため, 放流群間での殼高の差は放 流後の行動に影響を与えると考えられる。本研究では, 放 流 3 週間前のデータではあるが, 放流群間で殼高に大きな 差は見られなかった。また, 蓄養中の飼育条件は一定で 
あったことから, 放流時にも大きな差はなく, 放流後の行 動にも体サイズの差による影響は小さいと考えられた。実 際, 漁場から移出した個体としなかった個体との間で再捕 時の殼高の中央值の差は $0.8 \mathrm{~mm}$ であり大きな差は見られ なかった（Fig. 2)。

本研究では標識放流と再捕が複数年にわたって行われた が，環境要因の測定は単年しか行われなかった。しかしな がら, 対象海域の海藻藻場では 1 年を通してイソモク Sargassum hemiphyllum やトゲモク Sargassum micracanthum, ヤツマタモク Sargassum patens などの多年生ホンダワラ類 が優占しており, その分布範囲は 1994 年以降大きく変化 していないことが報告されている（新潟県 2018）。そのた め, 本研究期間内では藻場面積や岩場面積に経年的・季節 的変動は少なく, それら変動が解析へ与える影響は少ない と考えられた。

本研究では, 放流してから再捕までの時間経過と漁場の 形状および環境要因が移出に与える影響を明らかにするた め, LASSO-COX モデルを用いた。しかしながら, 実際 には移出してから再び放流漁場に回帰する個体や死亡した ために再捕されなかった個体が存在すると考えられる。本 研究での解析法ではこれら観測されなかった部分を报って いないために，推定結果は過小または過大評価かもしれな い。そのため，このような生存と再発見の過程を明示的に 記述できるモデル（例えば多状態モデル：Lebreton et al. 2009 など）を用いることが必要であろう。また, 本研究 では藻場や砂場といった底質環境にのみ着目したが, サザ エの移動や行動には放流海域の環境収容力, 捕食者や資源 をめぐる競合生物の存在など様々な要因が複雑に影響して いると考えられる。今後, これら要因にかかわる観察デー タの蓄積と複雑なデータ構造を柔軟にモデル化できる技術 の開発が望まれる。

これまで行われたサザエの放流試験では，その回収率が 約 13\%（井谷ら 1997）から 90\%（桑原ら 1986）まで大き く変動することが報告されている。これら報告間で放流サ イズや場所に違いはあるが, 井谷ら（1997）はこのばらつ きの原因の一つとして, 漁場内の餌環境や住み場所として の空間の多鿒によって漁場からの散逸の度合いが異なるこ とを指摘している。本研究における解析の結果, 藻場と岩 場面積の偏回帰係数は負の值であり, 藻場や岩場面積が大 きいほど放流漁場から移出しにくいことを表していた。こ れまでの研究では, サザエの分散抑制に関して餌料環境が 重要であることが指摘されている（井谷・宗清 1999）。主 にホンダワラ類が優占する海域では大型のアカモク Sargassum horneri やイソモクなどが重要な餌料の一つとさ れており（臀矢ら 1987, 山川・林 2004），本調查海域にお ける藻場もホンダワラ類が優占するガラモ場であるため, 藻場面積が大きい漁場ほどサザエの移出が低くなったと考 えられる。ただし, サザエの䬲料環境として小型紅藻類の 存在（道家ら 1998）や複数種によって構成される混合藻
場（Hayakawa et al. 2018）が重要であることも報告されて いる。また, 本研究では海藻藻場を䬺料環境のみとして 扱ったが, これまでの研究により海藻藻場が慨料環境だけ でなく生息場所としても機能していることが明らかとなっ ている。例えば，成長に伴ってサザエの生息場所がサンゴ 藻群落からアラメ・カジメ場に変化する (Hayakawa et al. 2018）ことや, 紅藻類の形態的特徵がサザエ稚貝の蝟集率 を高める（藤井ら 1988）ことなどが報告されている。そ のため, サザエの移動生態を哚く理解するために, 小型海 藻の定量的なデータや海藻藻場の持つ生息場としての重要 性を組み込んだ解析を行うことが必要であると考えられ た。

餌料環境とともにサザエの住み場所となる複雑な海底構 造も分散を抑制することが報告されている（道家ら 1998， 井谷・宗清 1999)。本研究における岩場は主に転石や岩盤 から構成されており, 砂場と比較して住み場所となる空間 が多い。このため, 岩場面積が大きい漁場ほど住み場所が 多く，サザエの移出率を低くさせたと考えられた。

一方で，サザエの移動分散がランダム歩行モデルで正確 に説明できることも報告されている（臀矢ら 1988）。サザ エの分散がランダムな拡散過程によるものであれば, 移出 イベントの起こりやすさには漁場の形状が強い影響を与え ると考えられるが, 本研究の結果では漁場形状の影響は低 いことが示された。これらの結果は解析に用いているス ケールが異なるため単純に比較することは難しいが, 本研 究の結果から漁場レベルでの移動分散を考える上ではラン ダムな拡散過程よりも植生や底質による分散抑制効果の方 が重要であると考えられた。

放流用種苗（款高：約 $16 \mathrm{~mm}$ ）を用いた水槽実験では, 構造物より餌（海藻）の方がサザエを分散させにくいこと が示されている（井谷・宗清 1999）。本研究で推定された 説明変数の偏回帰係数は藻場よりも岩場面積の方が負の值 で絶対值が大きく（Table 5)，この結果は藻場よりも岩場 のほうがサザエの移出率を下げることを示していた。本研 究で用いたサザエは殼高が $60 \mathrm{~mm}$ 前後であることや観察 時間が異なることを考慮すると単純に比較はできないが，こ れら結果の違いは対象とした海藻種の違いに起因するのか もしれない。これまでのサザエの研究ではアオサUlva sp. が 分散抑制効果を持つこと（井谷・宗清 1999）や紅藻類に 蝟集効果があること（藤井ら 1988）が報告されているが, 本研究では海藻藻場としてホンダワラ類しか対象としてお らず,これら小型海藻は藻場に含まれていない。そのた め, 本研究における藻場の分散抑制効果が低く見積もられ たのかもしれない。一方で, 砂場面積の偏回帰係数は正の 值であり, 砂場面積が大きいほど放流漁場から移出しやす いことが示された。これまでの研究においても, 砂泥域を 含む底質で放流サザエの成長や生残を観察した例（例えば 臀矢ら 1986）はあるが，植生や水深など他の要因の影響 を分離することはしていない。本研究では相関の高い説明 
変数を用いた解析において, Lasso 型正則化項をモデルに 導入することによって変数選択を行うことができ, その結 果として砂場面積が大きい漁場はサザエの放流場所として 適していないことが考えられた。一方で, 実際にサザエの 行動に与える影響においてはサザエが移動中にどれだけの 確率で藻場や砂場に遭遇するかと言うことも重要と考えら れる。本研究では各底質の面積そのものを用いたが, 今後 の解析では漁場内の各底質面積の割合を用いることも考慮 する必要があるだろう。また,これまでの研究において, 砂泥域の空間配置がサザエの移動を制限することも指摘 （角田 1989）されており, 本研究で考慮していない底質の 空間的な構造を考慮することも重要と考えられる。

人工種苗や小型サザエの放流において, 漁業者は再度捕 獲できることを期待して放流を行っているが, 放流環境に よってはサザエが散逸してしまい必ずしも十分に再捕でき るわけではない（例えば井谷ら 1997 ：約 13\%, 本研究：

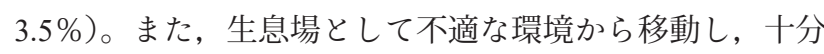
な隠れ場の乏しい環境に位置する機会が増えるほど, 捕食 者に発見される危険性が高まると考えられる。そのため, できる限り分散しにくい漁場に放流することや分散を抑制 できる環境を造成することがサザエ漁獲量や漁業生産額の 増大にとって重要であろう。本研究では, Lasso 型正則化 項の導入により相関の高い説明変数を含むモデルにおいて 変数選択を行うことができ, 底質がサザエの移動に影響し ている可能性を示した。これらの結果は, サザエ漁獲量の 増大を目的とした漁場整備や小型サザエの放流場所選定に おいて, 藻場だけではなく岩場や砂場に着目することも重 要であることを示している。

謝 辞: 研究を進めるうえで, 新潟漁業協同組合出雲崎支所の 方々には調查への便宜と多大なご協力を賜った。また, 北海道大 学の大久保祐作博士には LASSO 正則化についてご教示頂いた。 また, 担当編集者および 2 名の査読者にも, 重要かつ有益なコメ ントを賜った。ここに記して礼申し上げる。なお, 本研究は新 潟県資源管理協議会委託事業「資源管理体制高度化推進事業」と 水産庁水産基盤整備事業によって行われた。

\section{引用文献}

道家章生・宗清正廣・辻 秀二・井谷匡志 1998. サザエ漁獲礁の 効果. 水産工学 $35: 145-152$.
藤井明彦 1998. 対馬沿岸におけるサザエの資源生物学的研究. 長 崎県水産試験場研究報告 24: 69-115.

藤井明彦・四井敏雄・小川七朗 1988. サザエ稚貝の海藻に対する い集と摂餌. 長崎県水産試験場研究報告 14: 19-25.

Hastei T, Tibshirani R, Friedman J 2009. The Elements of Statistical Learning: Data Mining, Inference, and Prediction, Second edition. Springer, New York, 745 pp.

Hayakawa J, Ohtsuchi N, Kawamura T Kurogi H 2018. Ontogenetic habitat and dietary shifts in Japanese turban snail Turbo cornutus at Nagai, Sagami Bay, Japan. Fisheries Science 84: 201-209.

早川 淳・山川 卓・青木一郎 2007. アワビ類およびサザエ資源 の長期変動とその要因. 水産海洋研究 71: 96-105.

堀井豊充・藤井明彦・前迫信彦 1997. 放流漁場内におけるサザエ 種苗の移動, および放流個体数と可能漁獲量との関係につい て. 水産増殖 45: 187-193.

井谷匡志・宗清正廣 1996. 漁港内斜路におけるサザエ小型人工種 苗放流の試み。栽培技研 24: 71-73.

井谷匡志・宗清正廣 1999. サザエ放流種苗の分散抑制方法の検 討. 水産増殖 47: 9-14.

井谷匡志・宗清正廣・辻 秀二・道家章生 1997. 外洋域における サザエ人工種苗の放流. 京都海洋センター研報 19: 22-27.

海洋調查協会 2015. 海洋調査技術マニュアル. 海洋調查協会, 東 京, $161 \mathrm{pp}$.

角田信孝 1989. サザエ人工種苗の放流試験. 西海区ブロック藻 類・介類研究会報 6: 121-136.

桑原昭彦・臀矢 護・浜中雄一 1986. サザエ栽培漁業化に向け て. 日本海ブロック試験研究集録 8: 9-14.

Lebreton JD, Nichols JD, Barker RJ, Pradel R, Spendelow JA 2009. Modeling individual animal histories with multistate capture-recapture models. In Advances in Ecological Research Vol. 41, Caswell H (ed.), Academic Press, Burlington, pp. 87-173.

蓑谷千皨彦 1997. 計量経済学. 東洋経済新報社, 東京, $323 \mathrm{pp}$.

新潟県 2018. 本土沿岸地区藻場分布調査業務報告書. 新潟市, $269 \mathrm{pp}$.

R Development Core Team 2017. R: A language and environment for statistical computing. R Foundation for Statistical Computing, Vienna, Austria. http://www.R-project.org/ (accessed on 15 Feb 2019)

Tibshirani R 1996. Regression shrinkage and selection via the Lasso. Journal of Royal Statistical Society: Series B 58: 267-288.

山川 紘・林 育夫 2004. 新潟県粟島におけるサザエの消化管内 容物と海藻植生の関係. 水産増殖 52: 57-63.

臀矢 護 - 桑原昭彦 - 浜中雄一 - 和田洋藏 1987. 京都府青島地先 におけるサザエの食性. 日本水産学会誌 53: 1359-1366.

臀矢 護・桑原昭彦・过 秀二・内野 憲・田中雅幸 1988. サザ エの移動・分散と環境収容力. 京都海洋センター研報 11: 1-7.

臀矢 護 $\cdot$ 辻 秀二 ・道家章生 - 内野 憲 - 船田秀之助 1990. 冠 島におけるサザエ資源量の変動. 京都海洋センター研報 13: 21-28.

臀矢 護・和田洋藏・桑原昭彦・浜中雄一 1986. 放流サザエの成 長と生残. 日本水産学会誌 52: 41-47. 